\title{
リアルタイム水中ソナーを用いた 海上工事の施工・維持管理に向けた検討
}

\author{
道前 武尊 1 - 樋渡 和朗 2 - 帯田 俊司 3 - 琴浦 毅 4 - \\ 西畑 岡川5 - 平山 達也 6 - 野口 孝俊 7 \\ 1 五洋建設 (株) 技術研究所土木技術開発部 \\ ( ⿳ 329-2746 栃木県那須塩原市四区町 1534-1) \\ E-mail: Takeru.Michimae@mail.penta-ocean.co.jp \\ 2 五洋建設 (株) 船舶機械部（１ 112-8576 東京都文京区後楽 2-2-8） \\ E-mail: Kazuaki Hiwatari@ mail.penta-ocean.co.jp \\ 3 五洋建設 (株) 船舶機械部 (同上) \\ E-mail: Syunji Obita@mail.penta-ocean.co.jp \\ 4 正会員 五洋建設 (株) 技術研究所土木技術開発部 (T329-2746 栃木県那須塩原市四区町 1534-1) \\ E-mail: Tsuyoshi Kotoura@mail.penta-ocean.co.jp \\ 5 正会員 五洋建設 (株) 技術研究所土木技術開発部 (同上) \\ E-mail: Takeshi Nishihata@ mail.penta-ocean.co.jp \\ 6 五洋建設 (株) 船舶機械部 (下 112-8576 東京都文京区後楽 2-2-8) \\ E-mail: Tatsuya Hirayama@ mail.penta-ocean.co.jp \\ 7 正会員 国土交通省関東地方整備局 港湾空港部（干 231-8436 神奈川県横浜市北仲通 5-57)
}

E-mail: noguchi-t83ab@pa.ktr.mlit.go.jp

\begin{abstract}
建設産業における生産性向上，現場の労働力不足解消のため，港湾の「i-Construction」が推進されてい る . 港湾の「i-Construction」化を進めていく上では，水中部を高精度かつリアルタイムに可視化する技術 の開発が必要不可欠である.一般的に, 水中部の可視化に使われているナローマルチビームソナーは, リ アルタイムに水中部を把握するとは困難である . 本稿は , 水中部をリアルタイムに可視化可能な水中ソナ 一を用いた施工実験を実施し，ドック内を排水後に地上レーザー測量で施工出来形を測定した。施工出来 形と設計断面を比較することでリアルタイム水中ソナーを使用した際の施工精度，有用性を確認するとと もに,ノイズ処理による精度向上について評価したことを報告する．
\end{abstract}

Key Words : underwater, four-dimensional underwater visualization, wave dissipating block, 4D sonar system, noise processing, port construction, Port I-Construction

\section{1. はじめに}

建設産業における生産性向上を図るとともに , 現場の 労働力不足の解消のため，国土交通省を主体とした $\ulcorner$ i-Construction」への取り組みが進められている . 例と して，ドローンによる測量技術の開発や，建設機械の自 動化システムの開発か挙げられる.これらの陸上工事に おける生産性向上技術の開発はメディアなどにも取り上 げられ着実に進展がみられる。

港湾工事における生産性向上技術の開発を進めてい く上で重要になってくるのが水中部の「見える化」であ る . 港湾工事における水中施工では , 作業状況の視認が 困難なことにより，陸上施工と比較し，作業効率や施工 精度が低下する . 現在 , 一般的にナローマルチビームソ ナーが使用されているが, 2 次元ソナーという特性上，
リアルタイムに水中部を把握することは困難である . 水 中施工の生産性を向上させるためにはリアルタイムかつ 高精度な水中部可視化技術が必要とされている . また， 水中施工における機械化施工の導入や更なる潜水士の安 全性を向上させる技術の開発か求められている.

近年 , 港湾工事施工や維持管理の生産性向上に活用さ れ始めているリアルタイム水中ソナー (以降 , 水中ソナ 一と略記) がある . 水中ソナーはリアルタイムに水中部 を 3 次元として捕えることができ, 港湾工事の一役を担 い始めている . しかし, 水中ソナーの精度は, ナローマ ルチビーム , 水中スタッフと比較することて検証されて いるが，いずれの計測手法も陸上で用いられる計測手法 に対し誤差を有していることから，絶対的な精度検証が なされていない.また，すべての水中構造物を出来形管 理基隼值内に施工可能な精度を有していないこともあり 
補助的な役割にあまんじている．乥こで，本検討では水 中作業終了後に排水状態での測量が可能な大型ドック (水深 $6.0 \mathrm{~m}$ ) を用いて,精度検証とノイズ処理による精 度向上を図ることを目的とした。

\section{2. 水中ソナーシステム}

水中ソナーシステムの構成機器と仕樣を表-1 に示し， 特徵を以下に列記する .

- 海底地形や水中構造物の形状を 4 次元 $(X, Y, Z$, 時 刻)て計測し，表示およひ記録をすることができる．ソ ナーにより $50^{\circ} \times 50^{\circ}$ の範囲を $128 \times 128(16,384)$ 本の ビームを四角鍾状に照射し，最大 $150 \mathrm{~m}$ の距離まて計測 することができる .

・データ更新レートは最大 $12 \mathrm{f} / \mathrm{s}$ であるため, 水中の動体 計測も可能である . 船を静止させた状態でも計測するこ とができる .

表-1＼cjkstart水中ソナーシステムの構成機器と仕樣

\begin{tabular}{|c|c|c|}
\hline 機器 & \multicolumn{2}{|c|}{ 項目 } \\
\hline \multirow{12}{*}{ ソナー } & 周波数 & $375 \sim 700 \mathrm{kHz}$ \\
\hline & ビーム数 & $128 \times 128(16,384)$ \\
\hline & 最大レンジ & $150 \mathrm{~m}$ \\
\hline & 最少レンジ & $1 \mathrm{~m}$ \\
\hline & レンジ分解能 & $0.03 \mathrm{~m}$ \\
\hline & 更新レート & 最大 $12 \mathrm{f} / \mathrm{s}$ \\
\hline & 計測範囲 & $50^{\circ} \times 50^{\circ}$ \\
\hline & 1ビーム当たりの角度 & $0.39^{\circ}$ \\
\hline & ソナー寸法 & $380 \mathrm{~mm} \times 300 \mathrm{~mm} \times 160 \mathrm{~mm}$ \\
\hline & ソナー気中重量 & $22 \mathrm{~kg}$ \\
\hline & ソナー水中重量 & $12 \mathrm{~kg}$ \\
\hline & ソナ一耐水圧 & $600 m$ \\
\hline \multirow{7}{*}{$\begin{array}{c}\text { INS } \\
\text { (Inertial } \\
\text { Navigation } \\
\text { System) }\end{array}$} & 方位計測精度 & $0.01^{\circ}$ \\
\hline & ロール計測精度 & $0.01^{\circ}$ \\
\hline & ピッチ計測精度 & $0.01^{\circ}$ \\
\hline & ヒ一フ計測精度 & $5 \%$ or $5 \mathrm{~cm}$ \\
\hline & 出カレート & 最大 $100 \mathrm{~Hz}$ \\
\hline & 寸法 & $160 \mathrm{~mm} \times 160 \mathrm{~mm} \times 160 \mathrm{~mm}$ \\
\hline & 重量 & $4.5 \mathrm{~kg}$ \\
\hline \multirow{4}{*}{ RTK-GPS } & \multirow{2}{*}{ 精度 } & 水平 $8 \mathrm{~mm}+1 \mathrm{ppm}$ RMS \\
\hline & & 垂直 $15 \mathrm{~mm}+1 \mathrm{ppm}$ RMS \\
\hline & 更新レート & $20 \mathrm{~Hz}$ \\
\hline & 重量 & $1.55 \mathrm{~kg}$ \\
\hline
\end{tabular}


写真 1 水中ソナーシステム艤装状況
・水中ソナーを艤装した船体の動摇を INS(Inertial Navigation System : 慣性航法装置)て計測し，補正することが できる 超音波のノイズデータの除去も自動で行うため， 従来は不可能であったリアルタイムの 3 次元表示があら ゆるアングルで可能である.

・計測データは 4 次元て記録されているため，動画とし て再現が可能である .

・機器は重量 , 構成ともにナローマルチビームソナーと 同等て軽量かつ簡易であるため, 船体に後付けの艤装を することか可能であり，写真-1に示すように特定の船舶 や特別な装備を用意することなく対応することができる． ・作成した 3 次元モデルを水中ソナーシステム機器に取 り込み, 現地て映し出される 3 次元データと同時に表示 することが可能である .

\section{3. 現地実証実験概要}

\section{（1）実証フィールドの選定}

実証フィールドを選定する要素として以下の 3 点か学 げられる . 1 つ目として，実際の施工を再現するために は実物大の構造物を使用した試験を行う必要がある . 次 に，GPS(Global Positioning System)の取得および実海域の 海水再現のため, 周囲に GPS の電波を阻害する建造物が 無く海水か取水可能な゙海際の施設であること. 最後に , 施工後に高精度な陸上測量機器を用いて施工精度検証を 行うために，排水可能な施設であることであつた .

上記に述べた条件に対応する施設として，国土交通省 関東地方整備局か管理する大型ドックを実証フィールド として選定した .このドックは大正 15 年に完成し, 昭和 元年からこれまで, 主にケーソン製作か行われ港湾施設 整備に貢献してきた . 現在は次世代の海洋・港湾技術の 開発のために実証フィールドとして提供されている.こ のドックは, 幅 $23.3 \mathrm{~m} ・$ 延長 $109.0 \mathrm{~m} \cdot$ 最大水深 $8.5 \mathrm{~m}$ と 十分な大きさを有しており，周囲に高層な建造物もなく 実海域の海水を取水可能である .

\section{（2）実証フィールドの整備}

水中ソナ一は超音波を発し，跳ね返ってきた超音波を 受信することで 3 次元の点群データとして水中部の可視 化を行う . ドライドックのように閉鎖された空間におい ては実海域と異なり超音波力乱反射し, 精度の低下や取 得データに多量のノイズか発生する可能性がある. 対応 策としてドライドック底面に砕石を敷き均した これは， 実海域における海底地盤を再現する意味合いもある．

計測精度検証実験の観察対象物として鋼矢板(SP-II 型)と方塊ブロック $(1 \mathrm{~m} \times 1 \mathrm{~m} \times 1 \mathrm{~m})$ を注水前にドライドッ ク底面に設置した, 鋼矢板には $\varphi 1 \mathrm{~cm} \sim \varphi 30 \mathrm{~cm}$ の穴を設 


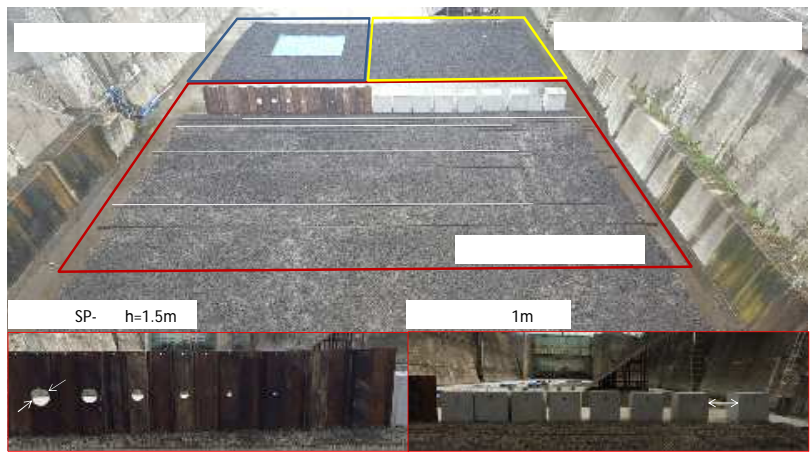

写真-2 実証フィールド整備完了

け, 方塊ブロックは $5 \mathrm{~cm} \sim 100 \mathrm{~cm}$ の目地間隔を変えて設 置した . また, 計測精度検証実験では水中ソナー単体の 計測精度検証を目的とするため,GPS および INS を使用 せず, $1.5 \mathrm{~m} \cdot 2.0 \mathrm{~m} \cdot 5.0 \mathrm{~m} \cdot 10.0 \mathrm{~m}$ の一定距離から対象物 を計測できるように底面にレールを設置した . (写真-2)

ドライドック内の砕石敷き均しおよひ観察対象物の設 置後, 水中ポンプにより水深 $6.0 \mathrm{~m}$ まで注水した .

\section{4. 消波工への導入 (消波ブロック据付実験)}

\section{(1) 3 次元モデルの作成}

現地実証実験を行うにあたり，消波ブロックの3 次元 モデルを作成した . また , ドック内を事前に測量を実施 し, 世界測地系で施工位置の座標を把握することで消波 ブロックの 3 次元モデルに座標データを付加させた .

本実証実験における消波ブロックの積み方は下段 9 個， 上段 4 個の水平 2 層積みとした , 消波ブロックの 3 次元 モデルを図1 1 に示す .

\section{(2) 施工方法}

水中ソナーを艤装した船舶を，消波ブロック据付実験 フィールドを計測可能な位置に固定し，固定点から映像 を取得し続けた . 3 次元モデルで表示した消波ブロック を目標とし水中ソナーから得られる映像をもとにオペレ 一ターか誘導・設置し, 設置後に吊具を切り離す. 消波 ブロック据付サイクルを写真-3に示す .

下段9個については, 将来的な機械施工を見越し, 潜 水士による玉外しが不要な自動切り離し装置を使用し， 設置を行った .

\section{(3) 施工結果}

2 段目については 1 段目の据付精度に影響を受け，正 確な据付精度の検証か涃難なため, 1 段目 (9 個分のうち 8 個分) についてのみ精度を評価した . 評価内容は各消 波ブロックについて, 設計位置からの水平変位および回



図-1＼cjkstart消波ブロック 3 次元モデル



写真-3 消波ブロック据付サイクル



図-2 施工・出来形管理図

転角とし，出来形管理図を图-2に示す．本実験では，水 平面であるドック底面に消波ブロックを設置するため， 高さ方向の評価は行わないものとした .

港湾管理基準に記載されている，水中部に構造物を設 置する精度目標の中で一番厳しい据付精度 $\pm 5 \mathrm{~cm}$ を据付 目標とした .

消波ブロックの据付向きによって据付精度に大きな差 が出る結果となった . 原因として , 写真-4に示すように ソナーに対して反射角が小さい据付向き(2)は視認性か高 く据付精度も良好な結果になったのに対し, ソナーに対 して反射角が大きい据付向き(1)は視認性が低いため据付 精度か悪くなったと考えられる。 
据付向き(1)に対する据付位置誤差は，X軸について最 大值で $1 \mathrm{~mm}$, 最小值で $75 \mathrm{~mm}, \mathrm{Y}$ 軸について最大值で $198 \mathrm{~mm}$ 最小值で $162 \mathrm{~mm}$ ，回転角について最大值で $3^{\circ}$ ， 最小值で $7^{\circ}$ ，平均值で $2^{\circ}$ となった。(表-2)

据付向き(2)に対する据付位置誤差は，X軸について最 大值で $20 \mathrm{~mm}$, 最小値で $39 \mathrm{~mm}, \mathrm{Y}$ 軸について最大值で $38 \mathrm{~mm}$, 最小值で $11 \mathrm{~mm}$ ，回転角について最大值で $3^{\circ}$ ， 最小值で $6^{\circ}$ ，平均值で $2^{\circ}$ となった。(表-2)

音波反射角がささ，視認性の高い条件では現状の出 来形管理基準に適応しており，水中構造物の自動据付に 対し，有用であることか確認された。また， 1 段目を高 精度に据えることで 2 段目についても潜水士による誘導 を必要とせず, 据付が可能であった . (写真-5)

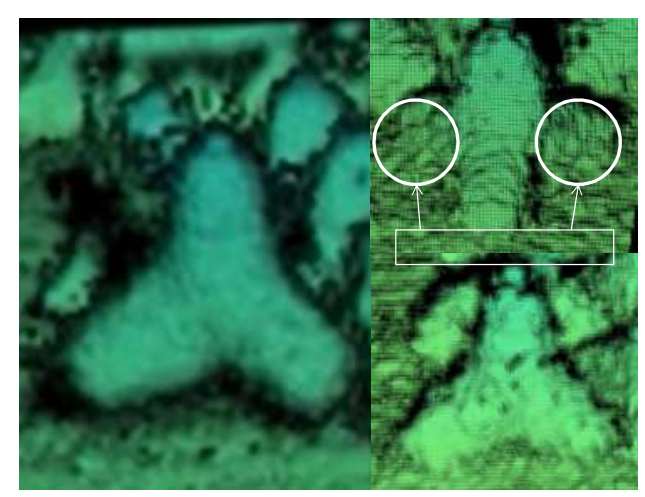

写真-4 据付向きによる違い

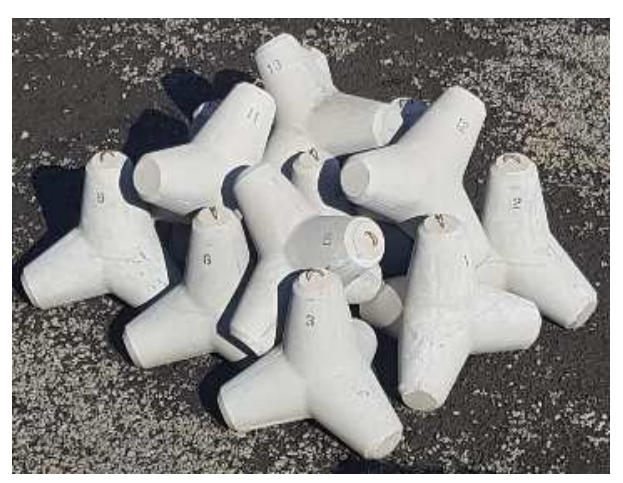

写真-5 消波ブロック据付完了

表-2 出来形管理表

\begin{tabular}{|c|c|c|c|c|c|c|}
\hline \multirow{3}{*}{ 据付番号 } & \multirow{3}{*}{ 据付向き } & \multicolumn{5}{|c|}{ 据付位置誤差 } \\
\hline & & \multicolumn{2}{|c|}{$\mathrm{x}$ 軸 $(\mathrm{mm})$} & \multicolumn{2}{|c|}{$\mathrm{y}$ 軸 $(\mathrm{mm})$} & \multirow{2}{*}{  } \\
\hline & & 出来形 & 目標値 & 出来形 & 目標値 & \\
\hline 1 & (1) & -75 & \multirow{9}{*}{ \pm 50} & 198 & \multirow{9}{*}{ \pm 50} & 3 \\
\hline 2 & (2) & -5 & & 4 & & -6 \\
\hline 3 & (2) & 20 & & 17 & & 3 \\
\hline 4 & (1) & 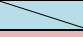 & & & & $x$ \\
\hline 5 & (2) & -39 & & 38 & & -1 \\
\hline 6 & (2) & -28 & & -11 & & -3 \\
\hline 7 & (1) & 1 & & 125 & & -7 \\
\hline 8 & (2) & 10 & & 36 & & -2 \\
\hline 9 & (2) & -15 & & 1 & & -3 \\
\hline \multirow{2}{*}{\multicolumn{2}{|c|}{$\begin{array}{l}\text { 据付向き(1) 平均値 } \\
\text { 据付向き(2) 平均值 }\end{array}$}} & -37 & & 162 & & -2 \\
\hline & & -10 & & 14 & & -2 \\
\hline
\end{tabular}

\section{5. 浚渫工への適用 (砂面形成実験)}

(1) 施工方法

砂面形成実験も消波ブロック据付実験と同樣に，世界 測地系の座標を保持した 3 次元モデルを作成し，砂を積 めたホッパーを水中ソナー映像をもとにしたオペレータ 一の誘導により投入位置へ移動した . 移動後, 潜水士に よりホッパーを開閉し，砂を投入，投入後，潜水士によ り $\varphi 5.0 \mathrm{~m}$, 高さ $0.8 \mathrm{~m}$ の円錐形状に均し, 港湾管理基準に 記載されている，水中土工の精度目標の中で一般的な精 度 $\pm 30 \mathrm{~cm}$ を目標とした 。

\section{(2) 施工結果}

ホッパーにより砂を投入する際に発生する濁りにより， 一時的に視認不能になる時間か存在した . ドライドック のような水の流れか無い場所では濁りか落ち着くまて作 業ができない結果となり，流れのない場所て砂等の巻き あがりのある対象物を施工する際は, 濁りに留意して施 工する必要がある。

図-3，4 に設計断面と出来形断面を比較した標高差の 分布図および分布表を示す . 比較方法は地上レーザー測 量によって得られた，出来形データをもとに，法線方向 と法線直角方向に対し法尻から $10 \mathrm{~cm}$ 間隔で格子を作成 し，各格子鉛直方向にあるデータの平均値を標高とした . 設計断面については各格子の中心位置の設計高さを使用 し, 出来形断面との比較を行った .

設計断面と出来形断面との標高誤差は最大値で $113 \mathrm{~mm}$, 最小值で-190mm , 平均値で $38 \mathrm{~mm}$ の施工精度 であることか確認された .

結果として , 港湾管理基準を十分に満たす施工が可能 であり，有用性か確認された .

一方で, 図-3を見て分かるように天端付近に向かって いくにつれ, 出来形断面の標高力設計に比べ低くなって いる . 原因として写真-6 に示すように , 排水時に表層の 砂が流出したことが考えられ，排水前は排水後の結果よ りも精度がよかったと考えられる。



写真-6 砂面形成完了 


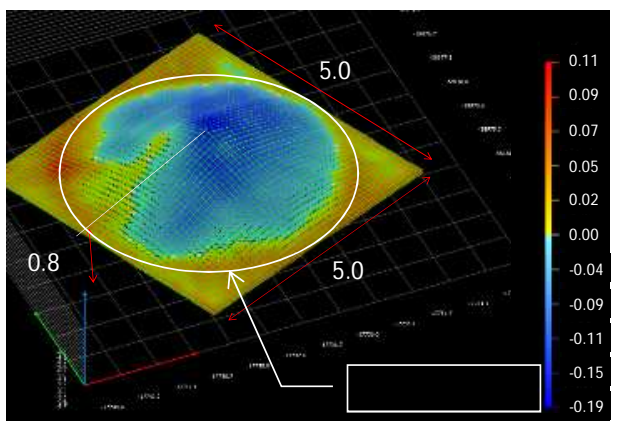

図-3 標高差分布図

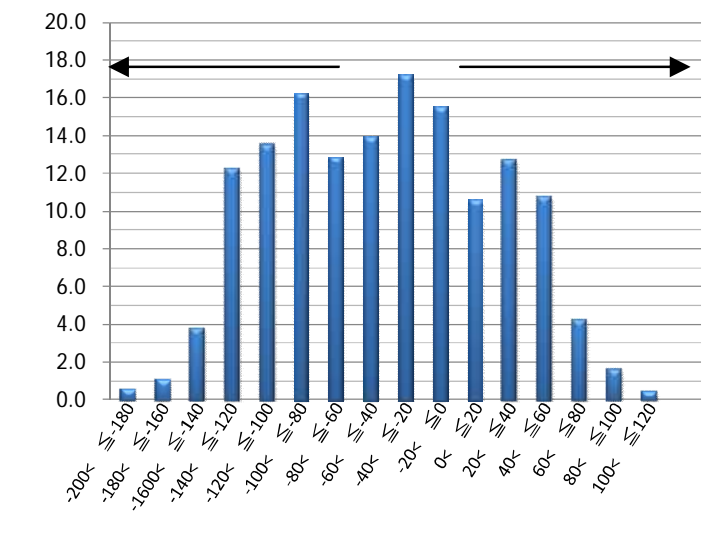

図-4 標高差分布表

\section{6. 維持管理への展開 (計測精度確認実験)}

(1) 測定方法

台車上に水中ソナーを固定し, フィールド整備の際に 設置したレール上を移動させることで観察対象物から一 定の距離 $(1.5 \mathrm{~m}, 2.0 \mathrm{~m}, 5.0 \mathrm{~m}, 10.0 \mathrm{~m})$ を保持した状態て計 測を行った。

観察対象は, 矢板法線, 方塊ブロック法線, 矢板の損 傷孔, 方塊ブロック間の隙間幅とし, 設置した鋼矢板に は損傷孔 $(\varphi 1 \mathrm{~cm}, \varphi 3 \mathrm{~cm}, \varphi 5 \mathrm{~cm}, \varphi 10 \mathrm{~cm}, \varphi 15 \mathrm{~cm}, \varphi 20 \mathrm{~cm}$, $\varphi 25 \mathrm{~cm}, \varphi 30 \mathrm{~cm})$ を設け, 方塊ブロックは隙間 $(5 \mathrm{~cm}, 10 \mathrm{~cm}$, $20 \mathrm{~cm}, 30 \mathrm{~cm}, 40 \mathrm{~cm}, 50 \mathrm{~cm}, 100 \mathrm{~cm})$ を設けて設置した . 潜水士により台車を観察対象の正面に水中ソナーが位置 するように移動させ , 固定点から計測を行った .

\section{(2) ノイズ除去方法}

本実験は，閉鎖空間であるドライドック内での測定で あるため，実海域にくらへてて多重反射による影響を受け て, 計測精度の低下がみられた，光こで, 水中ソナーか ら得られた点群データを以下に述べる 3 種類のフィルタ を使用してノイズ除去および統計処理を行った .

a) 水深フィルタ

床面 (海底面) から水面にかけての計測結果のみ表示 し 水面よりおよび床面からの反射ノイズをカットする．

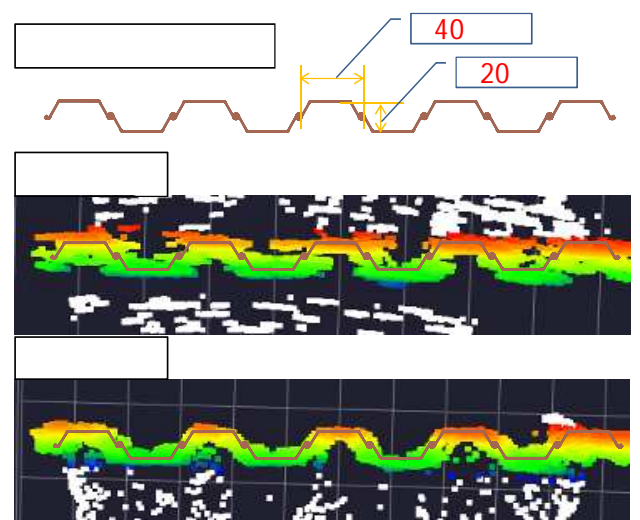

図-5 鋼矢板ノイズ処理前後比較 (上部から鋼矢板)

表-3ノイズ処理後の計測精度

\begin{tabular}{|c|c|c|c|c|}
\hline & \multicolumn{4}{|c|}{ 対応する計測精度 $(\mathrm{mm})$ 、判別可能な大きさ } \\
\hline 測定対象 & 測定距離1.5m & 測定距離 $2.0 \mathrm{~m}$ & 測定距離 $5 \mathrm{~m}$ & 測定距離 $10 \mathrm{~m}$ \\
\hline 矢板法線 & $\begin{array}{l}\sigma= \pm 11 \text { 前面) } \\
\sigma= \pm 20 \text { 背面) }\end{array}$ & $\begin{array}{l}\sigma= \pm 11 \text { 前面) } \\
\sigma= \pm 12 \text { 背面) }\end{array}$ & $\begin{array}{l}\sigma= \pm 30 \text { 前面) } \\
\sigma= \pm 17 \text { 背面) }\end{array}$ & $\begin{array}{l}\sigma= \pm 24 \text { 前面) } \\
\sigma= \pm 47 \text { 背面) }\end{array}$ \\
\hline ブロック法線 & $\sigma= \pm 20 \mathrm{~mm}$ & $\sigma \pm 19 \mathrm{~mm}$ & $\sigma \pm 13 \mathrm{~mm}$ & $\sigma \pm 17 \mathrm{~mm}$ \\
\hline 矢板損傷 孔径) & 20cmまで & $25 \mathrm{~cm}$ まで & $25 \mathrm{~cm}$ まで & 30cmまで \\
\hline $\begin{array}{c}\text { ブロック目地 } \\
\text { (幅) }\end{array}$ & 5cmまで & 10cmまで & 20cmまで & 30cmまで \\
\hline
\end{tabular}

b) 音圧フィルタ

音圧 $34 \mathrm{~dB}$ 以下の受信信号はノイズとしてカットし， ドック側面や多重反射に伴う計測ノイズか低減する効果 か期待される .

c) 統計処理フィルタ

ソナー計測距離方向の観測值について，9個 $\times 9$ 個分を 平均化することで計測面位置の計測精度向上を図る。

\section{(3) ノイズ除去結果}

上記のフィルタを用いて, 鋼矢板法線のノイズ処理前 後の計測平面図を図-5に示す . 矢板前面 (凸部, ソナー 側) のみならず, 背面 (凹部) においても計測精度の向 上が見られる .

各計測距離において, 同樣にフィルタ処理を行った際 の測定精度を表-3 に示す . 計測距離 $10 \mathrm{~m}$ 以内において , INS と GPS を併用せず,水中ソナー単体を用いた場合の 矢板およびブロック法線の計測精度が $\sigma 50 \mathrm{~mm}$ 以内に収 まることか確認できた .

一方で, 損傷孔径と目地幅の計測について, 計測距離 が $1.5 \mathrm{~m}$ の場合はブロック目地幅が $5 \mathrm{~cm}$ まで視認可能で あつたが, 船舶に艤装して運用するには計測距離が近す ぎる問題がある.現実的な運用距離である $10 \mathrm{~m}$ を超える とノイズ処理後でも損傷孔径や目地幅を確忍できる大き さとして $30 \mathrm{~cm}$ 以上が必要となる結果となった これは， 対象物までの計測距離が大きくなるにつれ，取得する隣 り合う点群同士の間䛿昿くなることが原因と考えられ る.これに関しては，機械性能としての向上は見込めな いため, 後処理による精度向上方法が必要となる。 


\section{7. まとめと今後の展望}

(1) まとめ

各実験結果に対してのまとめを以下に述べる .

a) 消波ブロック据付実験

·音波反射角が小さい向き，もしくは構造物の据付は， 測量による位置出しを行わずに, 水中構造物を港湾出来 形管理基準值内で据付けでき, 水中ソナ一の有用性か確 認できた .

・音波反射角が大きい向き，もしくは構造物の据付は大 きく据付精度が低下するため視認性を高めるための改善 が必要となる。

b) 砂面形成実験

・目標の管理基準である港湾出来形管理基準值内に収ま

り水中土工に対する水中ソナーの有用性か確認できた .

・閉鎖空間のように潮の流れがない場所で砂等を投入も

しくは掘削する場合は，砂等の巻上がりにより，作業が 止まる時間か発生することに，留意する必要がある。

c) 計測精度確認実験

・護岸の法線管理をしていく上での有用性か確認でき， 今後の護岸法線の管理に有用である

・閉鎖空間での精度向上がみられたため，実海域ではさ らなる精度向上か期待できる。

(2) 課題と今後の展望

各実験に対しての課題と今後の展望について以下に 述べる。

a) 消波ブロック据付実験

・水中ソナーに対して音波反射角が大きい構造物に対す

る表示方法や欠損部の補間方法の検討が必要である .

・水中構造物の据付を完全機械化施工するためには，吊
具を機械的に回転させることが可能な吊具の開発が必要

である。

b) 砂面形成実験

・浚渫や床堀など , 一定の濁度以上が発生する作業にお

いても視認性を確保できる必要があり，濁りによるノイ ズの処理方法力課題になる。

・水中ソナーのリアルタイム映像を潜水士が水中にて同 時に視認できる必要があり，視認用装置の開発が必要で ある 。

c) 計測精度確認実験

・今回使用したノイズフィルタをリアルタイムに機器に 実装することでさらなる精度向上が見込める．

なお，本検討は，国土交通省関東地方整備局「海洋・ 港湾技術の早期実用化に向けた実証実験」の公募に応募 し，選定された実験である．また，本研究の一部は，内 閣府総合科学技術・イノベーション会議の「SIP インフ ラ維持管理·更新・マネジメント技術」(管理法人:NEDO) に関連する研究開発として実施した。 こ協力いただきました関係各位に感謝いたします。

\section{参考文献}

1）港湾関連民間技術の確認審査・評価報告書第 12004 号 4D ソナーによる施工管理システム 一般財団法人沿 岸研究センター

2）眞鍋匠：4D ソナーによる施工管理システム，港湾荷 役, No.6, Vol58.pp.617-622, 2013.

3）野口孝俊，内藤裕之, 守屋典昭, 眞鍋近 : 4D ソナー システムを活用した航路障害物啓開作業の効率化に 向けた検討，土木学会論文集 B3 (海洋開発) No.2， Vol70.pp.990-995，2014，

(2017.2.2 受付)

\section{CONSIDERATION OF THE PORT CONSTRUCTION AND MAINTENANCE WHICH UTILIZED 4D SONAR SYSTEM}

\section{Takeru MICHIMAE, Kazuaki HIWATARI, Syunji OBITA, Tsuyoshi KOTOURA, Takeshi NISHIHATA, Tatsuya HIRAYAMA and Takatoshi NOGUCHI}

Construction industry is eager to promote the Port I-Construction which is domestic policy to solve labor shortage and productivity improvement. It is indispensable to visualize high precision and Real-time underwater structure for the Port I-Construction.

Generally, the Narrow multibeam surveying system is used for under water visualization. However , this system difficult to apply for Real-time visualization.

In this study, we conducted a series of experiment in dry dock to measure the underwater structures by using 4D sonar system. To evaluate the accuracy, the results were compared with that of ground laser measurement which was surveyed after drainage, and the design configuration.

To fulfill the requirements for Port I-Construction, a practical 4D sonar system which can survey the form, size, coordinates, etc. of the structures at Real-time was introduced. The accuracy, usefulness and noise processing method were taken into account for evaluation the applicability of the 4D sonar system in port and harbor works. 